\title{
Long-term ethanol exposure inhibits glucose transporter 4 expression via an AMPK-dependent pathway in adipocytes
}

\author{
Li FENG ${ }^{1,2, \# \text {, Yong-feng SONG }}{ }^{1, \#}$, Qing-bo GUAN ${ }^{1}$, Hong-jun LIU ${ }^{1}$, Bo BAN ${ }^{3}$, Hai-xin DONG ${ }^{3}$, Xiao-lei HOU ${ }^{1}$, Kok-onn LEE $^{4}$, \\ Ling $\mathrm{GAO}^{1, *}$, Jia-jun $\mathrm{ZHAO}^{1, *}$ \\ ${ }^{1}$ Provincial Hospital Affiliated to Shandong University; Institute of Endocrinology, Shandong Academy of Clinical Medicine, Ji-nan \\ 250021, China; ${ }^{2}$ Qianfoshan Hospital of Shandong Province, Ji-nan 250014, China; ${ }^{3}$ Hospital Affiliated to Ji-ning Medical University, \\ Ji-nin 272029, China; ${ }^{4}$ Division of Endocrinology, Department of Medicine, National University of Singapore, Singapore
}

\begin{abstract}
Aim: The roles of AMP-activated protein kinase (AMPK) and myocyte enhancer factor 2 isoforms (MEF2A, D) as mediators of the effects of ethanol on glucose transporter 4 (GLUT4) expression are unclear. We studied the effects of ethanol in adipocytes in vivo and in vitro.

Methods: Thirty-six male Wistar rats were divided into three groups and given ethanol in a single daily dose of $0,0.5$, or $5 \mathrm{~g} / \mathrm{kg}$ for 22 weeks. The expression of AMPK, MEF2 isoforms A and D, and GLUT4 was measured and compared in the three groups. The existence of the AMPK/MEF2/GLUT4 pathway in adipocytes and the effects of ethanol on this pathway were studied in (a) epididymal adipose tissue from six male Wistar rats subcutaneously injected with 5-aminoimidazole-4-carboxamide ribonucleoside (AICAR, an AMPK activator) or with $0.9 \% \mathrm{NaCl}$ (control); and (b) isolated rat and human adipocytes treated with or without ethanol, AICAR, and compound $\mathrm{C}$ (a selective AMPK inhibitor). Expression of AMPK, MEF2, and GLUT4 was measured by RT-PCR and Western blotting. Results: (1) Long-term ethanol exposure decreased activated AMPK, MEF2A, MEF2D, and GLUT4 expression in rat adipose tissue. (2) In rat and human adipocytes, AICAR-induced AMPK activation, with subsequent elevation of MEF2 and GLUT4 expression, was inhibited by compound C. (3) In vitro ethanol-treatment suppressed the AMPK/MEF2/GLUT4 pathway.

Conclusion: The AMPK/MEF2/GLUT4 pathway exists in both rat and human adipocytes, and activated AMPK may positively regulate MEF2 and GLUT4 expression. Ethanol inhibition of this pathway leads to decreased GLUT4 expression, thus reducing insulin sensitivity and glucose tolerance.
\end{abstract}

Keywords: ethanol; adipose tissue; AMP-activated protein kinase; myocyte enhancer factor 2; glucose transporter 4

Acta Pharmacologica Sinica (2010) 31: 329-340; doi: 10.1038/aps.2010.11; published online 22 February 2010

\section{Introduction}

Previous studies have demonstrated the important role of adipose tissue GLUT4 expression in determining insulin sensitivity. Adipocyte-specific GLUT4 ${ }^{-/-}$mice develop insulin resistance and glucose intolerance ${ }^{[1]}$, while mice with adiposespecific overexpression of GLUT4 have enhanced insulin sensitivity ${ }^{[2]}$.

The effect of ethanol on adipose tissue GLUT4 expression is complex. When rats are given a normal diet, chronic ethanol exposure is reported to decrease GLUT4 expression ${ }^{[3,4]}$

\footnotetext{
\# These authors contributed equally to this work.

* To whom correspondence should be addressed.

E-mail jjzhao@medmail.com.cn (Jia-jun ZHAO); gaoling1@medmail.com.cn (Ling GAO).

Received 2009-11-29 Accepted 2010-01-12
}

and surface accessibility ${ }^{[5]}$. However, when rats are given a high-fat diet, chronic ethanol administration increases GLUT4 expression $^{[6]}$. In addition, the mechanism of action of ethanol on GLUT4 is still obscure. In addition to the phosphoinositide 3-kinase (PI3K)-dependent pathway ${ }^{[7,8]}$, others have proposed that $\mathrm{G}$ protein ${ }^{[4,9]}$ and $\mathrm{Cb} 1 / \mathrm{TC} 0^{[10]}$ pathways are involved in the effect of ethanol on GLUT4. Recently, AMP-activated protein kinase (AMPK) has been suggested to be a new target for ethanol, but the effect of ethanol on AMPK activation is now controversial. Several groups have reported that AMPK activity could be inhibited by ethanol in both hepatic cells ${ }^{[11,12]}$ and brain cells of mice at postnatal day $7^{[13,14]}$. However, HongBrown reported that incubation of C2C12 myocytes with 100 $\mathrm{mmol} / \mathrm{L}$ ethanol markedly increases AMPK phosphorylation and activity ${ }^{[15]}$. Our previous study demonstrated that longterm ethanol exposure restores AMPK activity in the adipose 
tissue of high-fat diet-fed rats ${ }^{[6]}$.

The AMPK heterotrimer consists of a catalytic a subunit and two regulatory $\beta$ and $\gamma$ subunits ${ }^{[16,17]}$. There are multiple isoforms of each subunit: $\alpha 1$ and $\alpha 2 ; \beta 1$ and $\beta 2$; and $\gamma 1,2$, and $3^{[18]}$. AMPK is activated by a mechanism that involves allosteric modification and phosphorylation of Thr172 in the a subunit $^{[19]}$. Activated AMPK stimulates GLUT4 expression ${ }^{[20]}$ and basal GLUT4 translocation in both skeletal muscle and adipocytes ${ }^{[21-24]}$. Moreover, studies in cardiac and skeletal muscle have found that AMPK regulates GLUT4 in a manner dependent upon a heterodimer of MEF2A and MEF2D (myocyte enhancer factor 2) ${ }^{[25-27]}$, a complex that can bind to the human GLUT4 promoter $^{[26]}$ and thus regulate GLUT4 transcription.

In the present study, we investigated the effects of ethanol on the AMPK/MEF2/GLUT4 pathway in isolated rat and human primary adipocytes both in vitro and in vivo.

\section{Materials and methods Animal feeding}

Thirty-six male Wistar rats (weight, 160-180 g; Laboratory Animal Center of Shandong University) were housed in individual cages in a temperature-controlled room $\left(24^{\circ} \mathrm{C}\right)$ on a 12-h light-dark cycle and fed pelleted commercial normal chow diet containing $10 \%$ fat, $70 \%$ carbohydrate, and $20 \%$ protein (total $4.5 \mathrm{kcal} / \mathrm{g}$, Animal Center of Shandong University). After acclimatization for one week, the rats were divided into three groups and given edible ethanol (Ji-nan Baotu Spring Distillery, Shandong, China) at a single daily dose of $0.5 \mathrm{~g} / \mathrm{kg}$ body weight (low dose, group L) or $5 \mathrm{~g} / \mathrm{kg}$ (high dose, group $\mathrm{H}$ ) or distilled water (controls, group C) at 8-9 am by gastric tube. The animal study was approved by the Shandong University Institutional Animal Care and Use Committee (Ji-nan, China).

\section{Oral glucose tolerance test (OGTT)}

OGTT was carried out after a 22-week ethanol treatment. Rats were fasted overnight; blood glucose was then measured in samples obtained by tail bleeding before administration of glucose ( $2 \mathrm{~g} \cdot \mathrm{kg}^{-1}$ body weight) and at 30, 60, and $120 \mathrm{~min}$ after glucose. Blood glucose concentrations were determined using a One Touch SureStep Meter (Life Scan, Milpitas, CA). The area under the curve (AUC) was calculated to assess glucose tolerance.

\section{Determination of plasma ethanol concentration}

On the day of the study, two hours after ethanol administration, blood samples were obtained from the jugular sinus and were rapidly stored in tubes with seals. Plasma ethanol concentrations were determined using a dry chemical method (Johnson \& Johnson, USA).

\section{Tissue collection}

All rats were allowed to recover from OGTT for three days before sacrifice. Rats were anesthetized by an intraperitoneal injection of sodium pentobarbital $(0.1 \mathrm{~mL} / 100 \mathrm{~g} \mathrm{BW})$ after a 10-h fast. Blood samples were obtained from the inferior vena cava for glucose and insulin determination. Epididymal and perirenal fat pads were rapidly removed and weighed. Ratios of epididymal and perirenal adipose tissue weight $(\mathrm{g})$ to body weight $(\mathrm{g})$ were calculated. Portions of the epididymal fat samples were fixed in $4 \%(w / v)$ paraformaldehyde- $0.2 \mathrm{~mol} / \mathrm{L}$ phosphate-buffered saline (PBS, $\mathrm{pH} 7.4$ ) for immunofluorescence and hematoxylin \& eosin $(\mathrm{H} \& \mathrm{E})$ staining analysis. The remaining tissues were frozen in liquid nitrogen for messenger RNA and protein analyses.

\section{Biochemical analysis and evaluation of insulin sensitivity}

Blood glucose was measured using the glucose oxidase method. Insulin was measured by radioimmunoassay (Northern Bioengineering Institute, China). HOMA-IR was calculated using the following formula: FPG $(\mathrm{mmol} / \mathrm{L}) \times \mathrm{FINS}(\mathrm{mU} /$ $\mathrm{mL}) / 22.5^{[28]}$.

\section{AICAR injection}

Six male Wistar rats weighing 170-180 g were randomly divided into two groups and injected subcutaneously with AICAR (an AMPK activator, $0.8 \mathrm{mg} / \mathrm{g}$ body weight, AICAR group) or a corresponding volume of $0.9 \% \mathrm{NaCl}$ (control group). Two hours later, epididymal adipose tissues were obtained as described above for mRNA and protein analysis.

\section{Isolation of rat and human adipocytes}

Adipocytes were isolated from the epididymal fat pad of normal male Wistar rats (weighing 250-300 g) and from the omental adipose tissue of male patients aged 25-55 undergoing abdominal surgery at the Shandong Provincial Hospital (Jinan, China) in 2007. Patients with a history of ethanol ingestion or diabetes were excluded. All patients gave written informed consent for tissue donation before surgery. The human study was approved by the Ethics Committee of Shandong Provincial Hospital (Ji-nan, China).

All visible blood vessels were carefully removed from the fat tissue ${ }^{[29,30]}$. The fat pads were minced into millimeter-sized pieces, digested in Krebs-Ringer bicarbonate HEPES (KRBH) buffer $\left(120 \mathrm{mmol} / \mathrm{L} \mathrm{NaCl}, 4 \mathrm{mmol} / \mathrm{L} \mathrm{KH}_{2} \mathrm{PO}_{4}, 1 \mathrm{mmol} / \mathrm{L}\right.$ $\mathrm{MgSO}_{4}, 0.75 \mathrm{mmol} / \mathrm{L} \mathrm{CaCl}_{2}, 10 \mathrm{mmol} / \mathrm{L} \mathrm{NaHCO}_{3}, 30 \mathrm{mmol} / \mathrm{L}$ HEPES; pH 7.4) with $1 \mathrm{mg} / \mathrm{mL}$ collagenase type I, $1 \%(w / v)$ BSA, $2.5 \mathrm{mmol} / \mathrm{L}$ glucose, $100 \mu \mathrm{g} / \mathrm{mL}$ penicillin, $100 \mu \mathrm{g} / \mathrm{mL}$ streptomycin, and $1 \%(v / v)$ fungizone for $40-60 \mathrm{~min}$ in a $37^{\circ} \mathrm{C}$ water bath with gentle agitation. After being filtered sequentially through 500- and 250- $\mathrm{mm}$ nylon mesh, the adipocyte cell suspension was centrifuged at $800 \times g$ at room temperature for 2 min. After several washes, cells were resuspended in $\mathrm{KRBH}$ buffer ( $\mathrm{pH} 7.4$ ) with 1\% BSA and $2.5 \mathrm{mmol} / \mathrm{L}$ glucose, allowed to equilibrate for $30 \mathrm{~min}$ at $37^{\circ} \mathrm{C}$, and then used directly for the subsequent experiments. Cell concentration was adjusted to $1.0 \times 10^{6}$ cells $/ \mathrm{mL}$.

\section{Cell culture and treatment}

The isolated adipocytes were placed at a concentration of $1 \times 10^{7} / 100 \mathrm{~mm}$ per culture dish and incubated for $1 \mathrm{~h}$ in 
ethanol at a concentration of $100 \mathrm{mmol} / \mathrm{L}$. These conditions were determined from preliminary experiments designed to select the optimal time and dose response for AMPK phosphorylation. In the preliminary experiments, we found that $20 \mathrm{mmol} / \mathrm{L}$ ethanol positively regulated AMPK a phosphorylation, yet 50 and $100 \mathrm{mmol} / \mathrm{L}$ treatments decreased the response, and the inhibitory effect of ethanol became more obvious following an increase in ethanol concentration (data not shown). Additionally, ethanol concentrations of 50-200 $\mathrm{mmol} / \mathrm{L}$ are usually used in cell culture systems to observe the effect of high-dose ethanol ${ }^{[31-33]}$. Rat and human adipose cells were incubated at $37^{\circ} \mathrm{C}$ for $1 \mathrm{~h}$ in the absence or presence of ethanol (100 mmol/L), AICAR (1 mmol/L), and compound C (a selective inhibitor of AMPK, $20 \mu \mathrm{mol} / \mathrm{L}$ ). Compound C treatment was initiated $20 \mathrm{~min}$ before adding AICAR.

\section{RNA extraction and RT-PCR}

Total RNA was extracted from frozen epididymal adipose tissue and adipocytes using the standard Trizol RNA isolation method. The quality of RNA was checked using the DU640 nucleic acid analyzer (Beckman, USA). Reverse transcription of $4 \mu \mathrm{g}$ of RNA was carried out according to the instructions of the Fermentas RevertAid ${ }^{\mathrm{TM}}$ First Strand cDNA Synthesis Kit (\#K1622).

All primers were synthesized by the Shanghai Sangon Biotechnology Corporation (Shanghai, China) and the sequences are shown in Table 1. PCR amplification was carried out in a total reaction volume of $25 \mu \mathrm{L}$, including $2.5 \mu \mathrm{L}$ PCR buffer (10×), $0.2 \mu \mathrm{L}$ Taq polymerase, $2 \mu \mathrm{L}$ dNTP (TaKaRa, 2.5 $\mathrm{mmol} / \mathrm{L}), 2 \mu \mathrm{L} \mathrm{MgCl}_{2}$ (TaKaRa, $\left.25 \mathrm{mmol} / \mathrm{L}\right), 2 \mu \mathrm{L}$ primers $\left(5 \times 10^{-6} \mathrm{~mol} / \mathrm{L}\right)$ and $2.5-3 \mu \mathrm{L}$ of the cDNA $(2.5 \mu \mathrm{L}$ for AMPK $\mathrm{a} 1, \mathrm{a} 2$, and GLUT4; $3 \mu \mathrm{L}$ for MEF2A). The PCR products were subjected to $1.5 \%$ agarose gel electrophoresis containing ethidium bromide and visualized by excitation under UV light, quantified using Alphaimager 2200. GAPDH was used as an internal control for quantity and quality.

\section{Total, nuclear, and cytoplasmic protein extraction}

Epididymal adipose tissue samples were crushed into powder in liquid nitrogen. Either the tissue powder or the isolated adipocytes were lysed in RIPA buffer containing $1 \times$ PBS, $1 \%$ NP-40, 0.1\% SDS, $5 \mathrm{mmol} / \mathrm{L}$ EDTA, 0.5\% sodium deoxycholate, $1 \mathrm{mmol} / \mathrm{L}$ sodium orthovanadate, and $1 \%$ phenylmethylsulfonyl fluoride. The lysate was sonicated twice for $10 \mathrm{~s}$ each on ice and centrifuged at $12000 \times \mathrm{g}$ for $8 \mathrm{~min}$ at $4{ }^{\circ} \mathrm{C}$. Below the lipid layer, the soluble supernatant was carefully removed, avoiding the unhomogenized material at the bottom of the centrifuge tube, to obtain total protein. Nuclear and cytoplasmic proteins were prepared using NE-PER Nuclear and Cytoplasmic Extraction Reagents (Pierce). Protein content was measured using the Lowry Protein Assay Kit (Bio-Rad, USA).

\section{Western blotting}

Protein samples $(60 \mu \mathrm{g})$ were resolved by SDS-PAGE $(10 \%$ resolving gels for total $\mathrm{AMPKa}$, phosphorylated $\mathrm{AMPKa}$, total-MEF2, MEF2A, MEF2D, and GLUT4; 6\% resolving gels for phosphorylated acetyl-CoA carboxylase, pACC) and transferred to polyvinylidene difluoride membranes (Millipore, Billerica, MA, USA). All membranes were incubated overnight at $4{ }^{\circ} \mathrm{C}$ with primary antibodies against total AMPKa (rabbit polyclonal antibody, 1:1000 dilution, Cell Signaling, Danvers, MA,USA), pAMPKa (rabbit polyclonal antibody, 1:1000 dilution, directed against both a1 and a2 isoforms of the enzyme phosphorylated at Thr172, Cell Signaling, Danvers, MA,USA), pACC (rabbit polyclonal antibody, Ser-79; 1:1000 dilution, Cell Signaling, Danvers, MA, USA), MEF2 (rabbit polyclonal antibody, 1:100 dilution, Santa Cruz, USA), MEF2A (rabbit monoclonal antibody, 1:1000 dilution, Abcam Ltd, Cambridgeshire, UK ), MEF2D (goat polyclonal antibody,

Table 1. Sequences of primers and annealing temperatures.

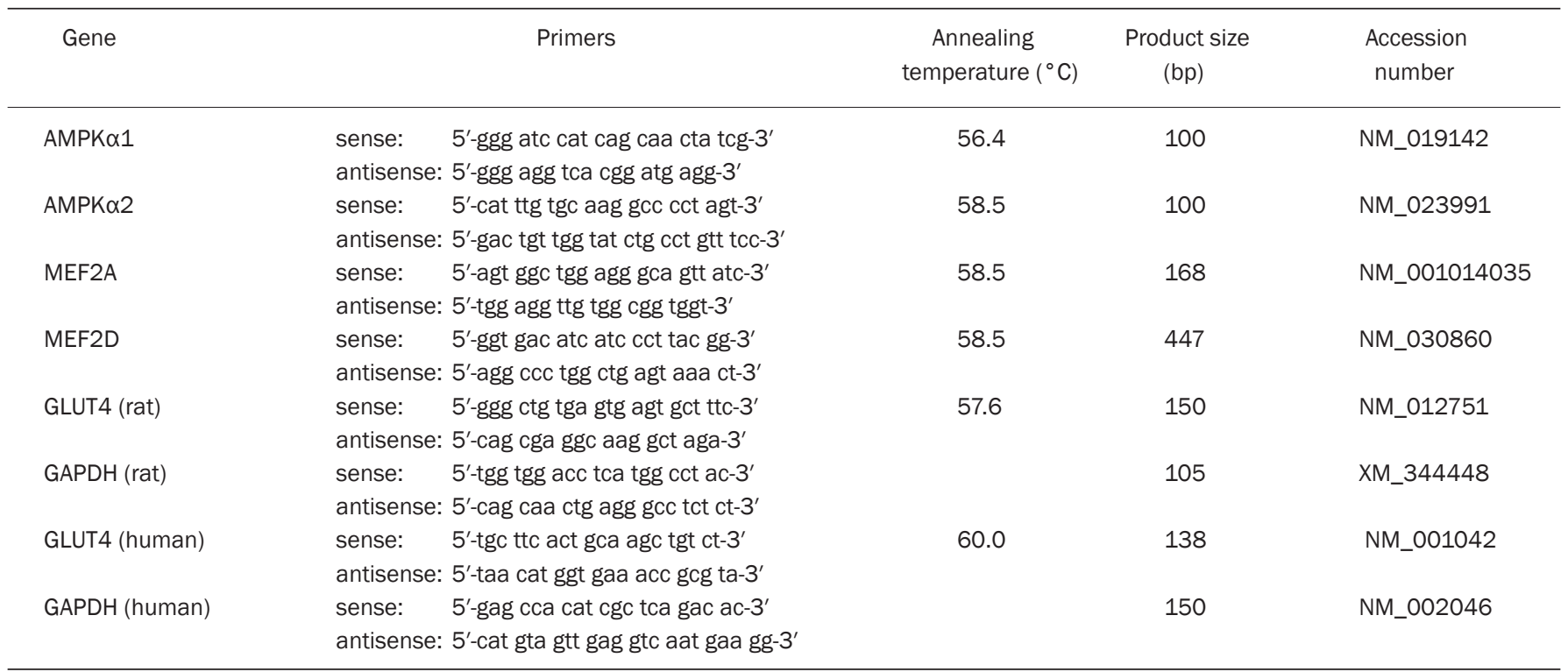


1:200 dilution, Santa Cruz, USA), or GLUT4 (rabbit polyclonal antibody, 1:2500 dilution, Abcam Ltd, Cambridgeshire, UK). After incubation with secondary antibody (Zsbio, Ltd, China), immune complexes were detected using Amersham ECL Plus $^{\mathrm{TM}}$ Western Blotting Detection Reagents (Amersham, UK), and immunoreactive bands were quantified using Alphaimager 2200. Expression of $\beta$-actin was measured as an internal loading control by reblotting the membranes with mouse antirat $\beta$-actin monoclonal antibody (1:10000 dilution, Abcam Ltd, Cambridgeshire, UK). The relative target protein levels were normalized to $\beta$-actin.

\section{Immunofluorescence and hematoxylin and eosin (H\&E) staining}

The fixed epididymal adipose tissue was embedded in paraffin, and $5-\mu \mathrm{m}$ sections were obtained. The glass-mounted sections were cleared from paraffin with xylene and rehydrated by sequential washings with graded ethanol solutions $(70 \%-100 \%)$, subsequently incubated in 3\% $\mathrm{H}_{2} \mathrm{O}_{2}$ in methanol for $10 \mathrm{~min}$ to quench the endogenous peroxidase activity, pretreated in a microwave oven in sodium citrate buffer ( $\mathrm{pH} 7.4$ ) for 20 min with the temperature always kept at $95-98{ }^{\circ} \mathrm{C}$, and then cooled at room temperature for $20 \mathrm{~min}$ to ensure recovery of protein spatial configuration. After being washed with PBS, the sections were blocked by $10 \%$ secondary antibody homologous sera (goat serum) in PBS for $2 \mathrm{~h}$ at room temperature, followed by overnight incubation with the primary antibody (rabbit anti-GLUT4, 1:300 dilution) in 5\% goat serum in PBS at $4{ }^{\circ} \mathrm{C}$ in a moisture chamber. Negative controls for immunospecificity were included in all experiments, and the primary antibody was replaced by PBS or matching concentrations of normal rabbit or mouse serum ${ }^{[34]}$. All sections were then incubated with a FITC-conjugated anti-rabbit secondary antibody (1:150 dilution) for $1 \mathrm{~h}$ at room temperature. After sections were mounted with DAPI in PBS, analysis and photodocumentation were performed using a fluorescent microscope (Leica Microsystems GmbH, Wetzlar, Germany). The obtained sections were also stained with H\&E and then examined under an optical microscope.

\section{Statistical analyses}

All of the experiments were repeated at least four times. All values are presented as means $\pm S D$. Data were analyzed using SPSS 11.5 software (SPSS, Inc, Chicago, IL). Statistical significance was assessed by one-way ANOVA. $P<0.05$ was considered statistically significant.

\section{Results}

\section{Characteristics of rats after 22-week treatment}

As shown in Table 2, all three groups were of similar body weights at baseline. After 22 weeks of treatment, ethanol-fed rats showed lower body weights, and high-dose ethanol feeding led to a greater reduction in body weight than low-dose ethanol (393.8 \pm 56.5 vs $456.7 \pm 62.6, P<0.05)$, but only the body weight of the high-dose ethanol group (group $\mathrm{H}$ ) was statistically significant compared with that of the controls $(393.8 \pm 56.5$ vs $477.7 \pm 34.5, P<0.01)$. Long-term high-dose ethanol administration significantly increased the ratio of epididymal adipose tissue to total body weight compared to both low-dose ethanol and distilled water consumption groups $(1.2 \pm 0.3$ vs $0.9 \pm 0.2$, $P<0.05$ vs group $L ; 1.2 \pm 0.3$ vs $0.9 \pm 0.3, P<0.05$ vs group $C)$ but had no significant influence on perirenal fat mass. By contrast, low-dose ethanol consumption did not significantly change the mass of adipose tissue in either site relative to the controls.

Although high-dose ethanol administration increased fasting plasma glucose levels, the value was not statistically significant. Compared to groups $\mathrm{L}$ and $\mathrm{C}$, fasting serum insulin levels were markedly elevated in group $\mathrm{H}(28.4 \pm 6.1$ vs $22.0 \pm 5.6$, $P<0.05$ vs group $\mathrm{L} ; 28.4 \pm 6.1$ vs $20.6 \pm 5.2, P<0.05$ vs group $\mathrm{C})$. Similarly, HOMA indexes, which were used to evaluate insulin sensitivity, were significantly increased after high-dose ethanol administration $(4.5 \pm 1.0$ vs $3.4 \pm 1.0, P<0.05$ vs group $L$; $4.5 \pm 1.0$ vs $3.2 \pm 1.2, P<0.05$ vs group $C$ ) but were not markedly elevated in group $\mathrm{L}(3.4 \pm 1.0$ vs $3.2 \pm 1.2, P>0.05)$ compared to the controls.

\section{Long-term ethanol consumption induces glucose intolerance in rats}

Long-term ethanol consumption, both in low and high dosages, increased glucose levels at the time points before and after the glucose load, but the increases were not significant. Deterioration in glucose tolerance $(11 \%$ enhancement in glucose AUC, $P<0.05$ vs controls) was observed in high-dose etha-

Table 2. Characterization of the Rats in 3 diet groups. ${ }^{b} P<0.05,{ }^{c} P<0.01$ vs Controls. ${ }^{e} P<0.05$ vs the low-dose ethanol group.

\begin{tabular}{lccc}
\hline & $\begin{array}{c}\text { Low-dose ethanol group } \\
(n=12)\end{array}$ & $\begin{array}{c}\text { High-dose ethanol group } \\
(\text { Initial: } n=12 ; \text { Final: } n=10)\end{array}$ & $\begin{array}{c}\text { Controls } \\
(n=12)\end{array}$ \\
& & & \\
BW (g) & $224 \pm 16.9$ & $224.9 \pm 18.3$ & $220.3 \pm 13.1$ \\
Initial & $456.7 \pm 62.6$ & $393.8 \pm 56.5^{\text {ce }}$ & $477.7 \pm 34.5$ \\
Final & $0.9 \pm 0.2$ & $1.2 \pm 0.3^{\text {be }}$ & $0.9 \pm 0.3$ \\
Epididymal fat mass (\% of BW) & $1.1 \pm 0.4$ & $1.2 \pm 0.7$ & $1.3 \pm 0.6$ \\
Perirenal fat mass (\% of BW) & $3.44 \pm 0.38$ & $3.6 \pm 0.36$ & $3.46 \pm 0.23$ \\
FBG (mmol/L) & $22.0 \pm 5.6$ & $28.4 \pm 6.1^{\text {be }}$ & $20.6 \pm 5.2$ \\
FINS(mIU/L) & $3.4 \pm 1.0$ & $4.5 \pm 1.0^{\text {be }}$ & $3.2 \pm 1.2$ \\
HOMA-IR & $4.4 \pm 0.6$ & $87 \pm 24.9$ & $0.3 \pm 0.01$ \\
Plasma ethanol concentration $(\mathrm{mg} / \mathrm{dL})$ & & & \\
\hline
\end{tabular}


nol fed rats. Low-dose ethanol had no marked influence on glucose tolerance relative to the controls (Figure 1).
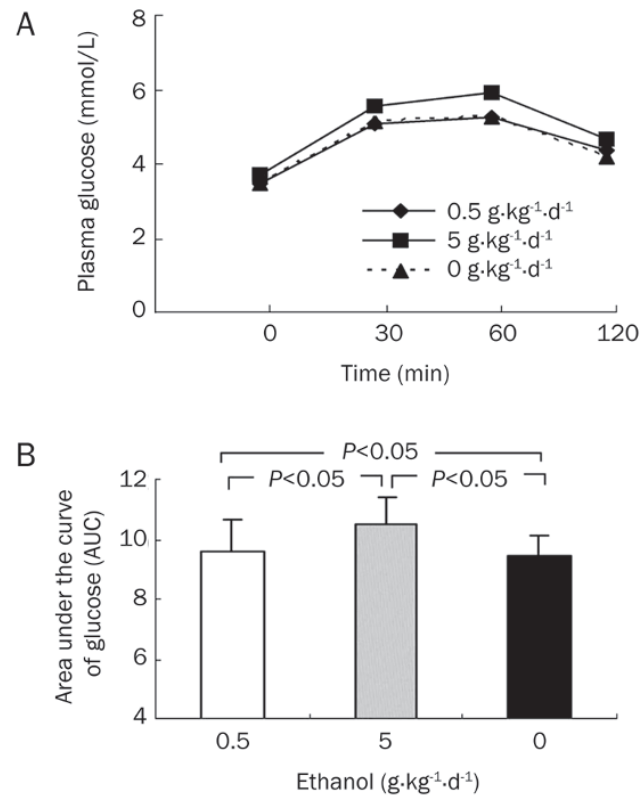

Figure 1. Long-term ethanol exposure induced glucose intolerance in rats. Thirty-six male Wistar rats were divided into three groups and received edible ethanol with a single daily dose of 0.5 or $5 \mathrm{~g} / \mathrm{kg}$ or distilled water. Twenty-two weeks after, oral glucose tolerance test (OGTT) was carried out. Blood glucose levels were measured from samples obtained by tail bleeding before administration of glucose ( $2 \mathrm{~g} / \mathrm{kg}$ body weight) by gavages, and 30,60, $120 \mathrm{~min}$ after the glucose load (A). Area under the curve (AUC) was calculated to assess glucose tolerance (B). Values are given as means $\pm S D$ ( $n=12$ for the low-dose ethanol and control group, $n=10$ for the high-dose ethanol group).

\section{Long-term ethanol feeding reduces GLUT4 expression in rat} adipose tissue

In epididymal adipose tissue of ethanol-fed rats, GLUT4 mRNA levels decreased by $28 \%$ (group L, $P<0.05$ ) and $47 \%$ (group $\mathrm{H}, \mathrm{P}<0.01$ ), respectively (Figure $2 \mathrm{~A}$ ), and the corresponding protein levels decreased by $21 \%$ (group L, $P<0.05$ ) and $40 \%$ (group $\mathrm{H}, \mathrm{P}<0.01$ ), respectively, relative to the controls (Figure 2B). High-dose ethanol had a greater inhibitory effect on GLUT4 mRNA and protein expression than lowdose ethanol (both $P<0.05$ vs group L). To confirm the action of ethanol on GLUT4 expression, adipose tissue sections were stained by immunofluorescence. The specific immunofluorescence signal was absent in the negative control sample. Compared to non-ethanol-fed rats, weaker signals for GLUT4 expression were observed in the ethanol-fed rat adipose tissue, and the effect of ethanol was dose dependent (Figure 2C). These data show that ethanol feeding decreased GLUT4 expression in rat adipose tissue.

\section{Ethanol suppresses MEF2 expression}

With the description of a functional MEF2A/MEF2D heterodi-
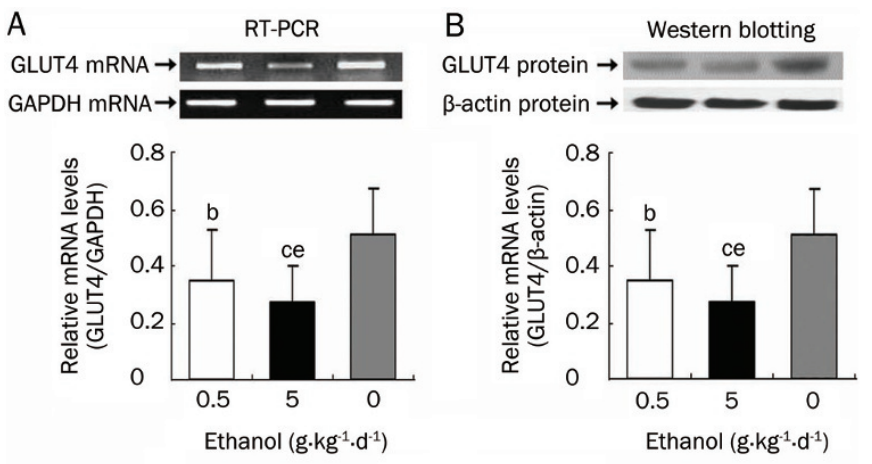

C
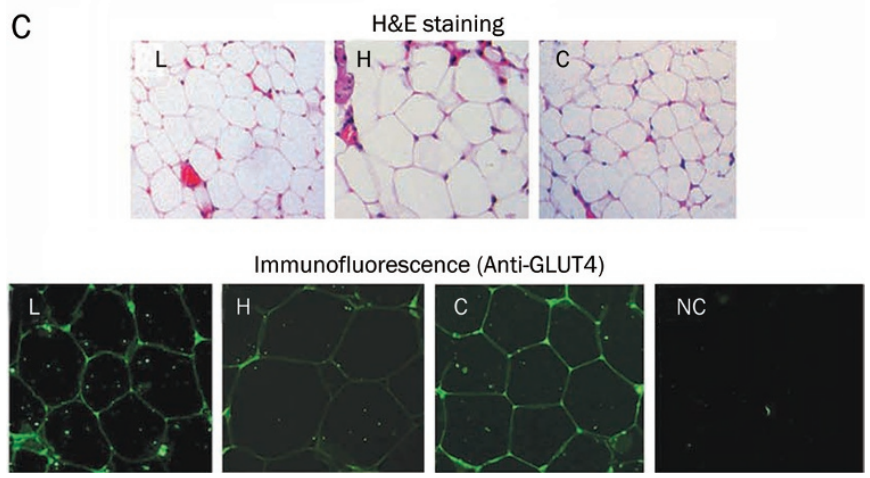

Figure 2. Long-term ethanol exposure decreased GLUT4 mRNA and protein expression in rat adipose tissue. After feeding rats with ethanol at the dosage of $0,0.5$ or $5 \mathrm{~g} \cdot \mathrm{kg}^{-1} \cdot \mathrm{d}^{-1}$ for 22 weeks, we determined GLUT4 mRNA levels by RT-PCR (A), protein levels by Western blotting (B) and immunofluorescence $(\times 200, C)$. Hematoxylin and eosin $(H E)$ stain $(\times 200)$ was performed to observe the appearance of the adipocytes after ethanol treatment. GLUT4 mRNA levels were normalized by GAPDH, and protein levels were normalized by $\beta$-actin. Values are given as means $\pm S D(n=12$ for the low-dose ethanol and control group, $n=10$ for the high-dose ethanol group). L, low-dose ethanol group. H, high-dose ethanol group. C, controls. NC, negative controls. ${ }^{b} P<0.05,{ }^{c} P<0.01$ vs controls. ${ }^{e} P<0.05$ vs the low-dose ethanol group.

mer binding site in the rat and human GLUT4 promoters $^{[3,36]}$, MEF2 is considered a transcriptional regulator of GLUT4. To explore whether MEF2 was involved in the inhibitory effect of ethanol on GLUT4 expression, we measured the expression of total MEF2 and its two isoforms, MEF2A and D, in adipose tissue exposed to ethanol. Figure $3 \mathrm{~A}$ shows that while the MEF2A mRNA level was not affected by ethanol, the MEF2D isoform was reduced by $9 \%$ in group $\mathrm{L}(P>0.05)$ and $23 \%$ in group $\mathrm{H}(P<0.01)$ relative to the controls (Figure $3 \mathrm{~A})$. The total MEF2 protein levels were correspondingly decreased by $24 \%(P<0.05)$ and $33 \%(P<0.05)$ in groups $\mathrm{L}$ and $\mathrm{H}$, respectively, versus the controls (Figure $3 \mathrm{~B}$ ). The difference in MEF2D mRNA between groups $\mathrm{H}$ and $\mathrm{L}$ was statistically significant $(P<0.05$, Figure $3 \mathrm{~A}$ and $3 \mathrm{~B})$. Similarly, total MEF2 protein levels were affected by the different dose of ethanol $(P<0.05$, Figure $3 \mathrm{~B})$. We hypothesized that the ability of ethanol to decrease MEF2D mRNA expression might contribute, at least partially, to a decline in MEF2D protein. To test this, we measured the nuclear and cytoplasmic expression of MEF2D 
A

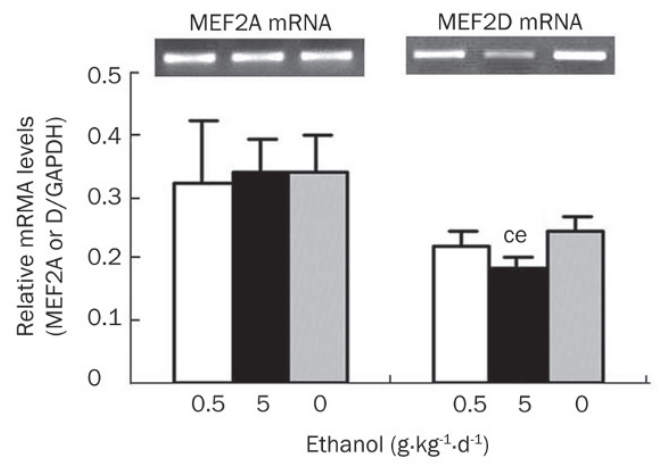

B
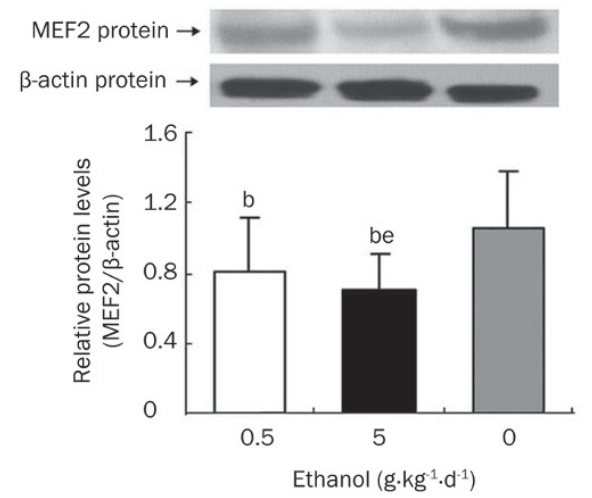

C

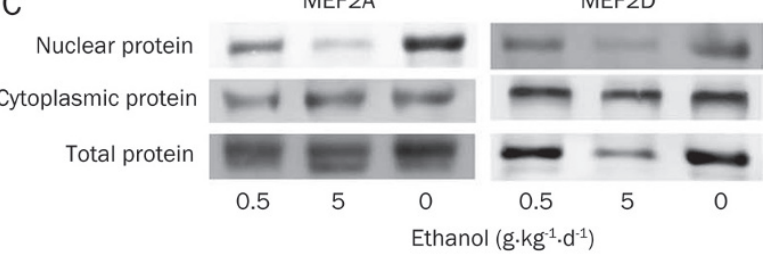

Figure 3. Effect of long-term ethanol administration on MEF2 expression in rat adipose tissue. After rats were fed with edible ethanol at the daily dosage of 0 (control), 0.5 , or $5 \mathrm{~g} \cdot \mathrm{kg}^{-1} \cdot \mathrm{d}^{-1}$ for 22 weeks, by using RT-PCR and Western blotting, we determined MEF2 expression both at mRNA (A) and total protein (B) levels. We also measured nuclear, cytoplasmic, and total proteins of MEF2A and D, two isoforms of MEF2 (C) in adipose tissue. MEF2A, D mRNA levels were normalized by GAPDH and MEF2 protein levels were normalized by $\beta$-actin. Values are given as means $\pm S D$ ( $n=12$ for the low-dose ethanol and control group, $n=10$ for the high-dose ethanol group). ${ }^{b} P<0.05,{ }^{c} P<0.01$ vs controls. ${ }^{e} P<0.05$ vs the low-dose ethanol group.

in adipocytes. Our results show that ethanol treatment decreased MEF2D protein expression and there was a notable difference between groups $\mathrm{H}$ and $\mathrm{L}$, not only in whole cell extracts but also in nuclear and cytoplasmic extracts (Figure 3C). Moreover, for an analysis of MEF2A isoform, although the total MEF2A protein expression in group $\mathrm{L}$ and $\mathrm{H}$ was of no statistical significance relative to the control, the nuclear MEF2A level in group $\mathrm{H}$ was markedly lower than that in group L and C (Figure 3C).
Long-term ethanol feeding impairs AMPK activation but not expression

Recently, AMPK has been suggested as a new target for ethanol. Studies in skeletal muscle have shown that AMPK regulates GLUT4 via MEF2. To explore whether the decreased MEF2 and GLUT4 expression after ethanol treatment in adipose tissue was associated with the inhibition of AMPK, we measured the expression of AMPKa1 and a2 mRNA and total AMPKa and pAMPKa protein in rat adipose tissue.

Our results show that mRNA expression of the AMPKa1 and a2 isoforms in ethanol-fed rats was not statistically different from that in control rats (Figure 4A). Consistent with this result, total AMPKa protein was also not affected by long-term ethanol feeding (Figure 4B). However, in ethanol-fed groups, the bands of phosphorylated AMPK protein detected by Western blotting were fainter than those in the control group $(21 \%$ decrease in group $\mathrm{L}, P<0.05 ; 41 \%$ decrease in group $\mathrm{H}, P<0.01$ ). Moreover, a much fainter phosphorylated AMPKa band was found in group $\mathrm{H}$ compared to group $\mathrm{L}(P<0.05$, Figure $4 \mathrm{~B})$, indicating that ethanol feeding impairs AMPK activation and that the impairment effect correlates with the ethanol dosage.
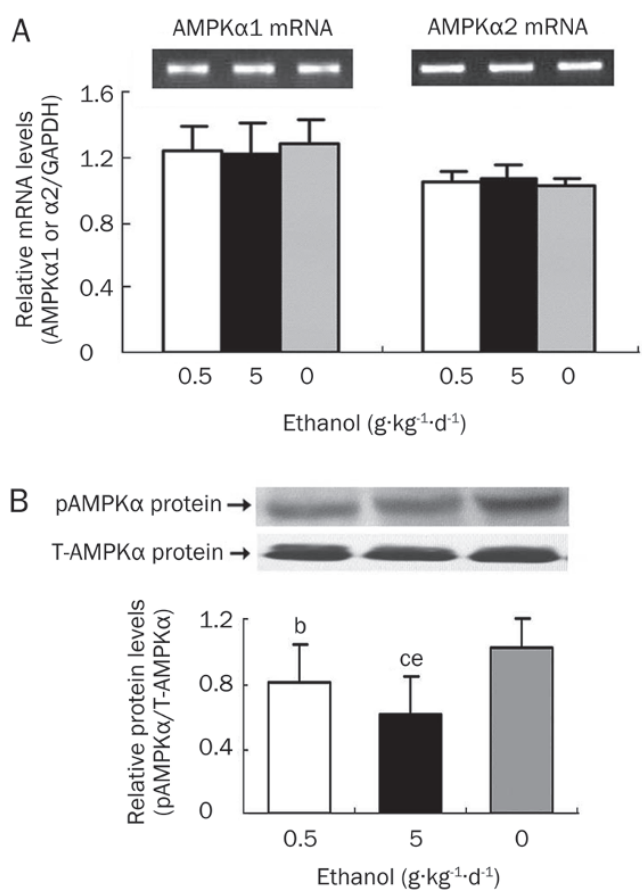

Figure 4. Long-term ethanol exposure impaired activation, but not expression of AMPK in rat adipose tissue. After feeding rats with ethanol at the daily dosage of $0,0.5$, or $5 \mathrm{~g} \cdot \mathrm{kg}^{-1} \cdot \mathrm{d}^{-1}$ for 22 weeks, we determined mRNA levels of AMPK $\alpha 1$ and $\alpha 2$ isoforms by RT-PCR (A), protein levels of total-AMPK (T-AMPK) and phosphorylated-AMPK (PAMPK) by Western blotting (B). mRNA expression was normalized by GAPDH, and protein expression was normalized by $\beta$-actin. Values are given as means $\pm S D$ ( $n=12$ for low-dose ethanol and control group, $n=10$ for high-dose ethanol group). ${ }^{b} P<0.05,{ }^{c} P<0.01$ vs controls. ${ }^{e} P<0.05$ vs the low-dose ethanol group. 
Activated AMPK positively regulates MEF2 and GLUT4 expression in rat adipose tissue

Activated AMPK has been reported to regulate GLUT4 expression via MEF2 in skeletal muscle. In the present study, we found consistent changes in pAMPKa, MEF2, and GLUT4 in adipose tissue after long-term ethanol exposure, which prompted us to hypothesize that in adipose tissue, inhibition of AMPK activation might also result in decreased MEF2, which subsequently decreases GLUT4 expression. To test our hypothesis, rats were injected with AICAR. AICAR injection led to a marked increase in AMPKa phosphorylation in rat adipose tissues. As an indicator of AMPK activation, pACC was enhanced accordingly, indicating that the phosphorylation of AMPKa was followed by increased activity. Following the activation of AMPK, MEF2 protein level was elevated. As a result, GLUT4 mRNA levels were increased and, subsequently, its protein level increased. Our data show that activation of AMPK up-regulated MEF2 expression, with subsequent increases in GLUT4 expression in adipose tissue in vivo (Figure 5).

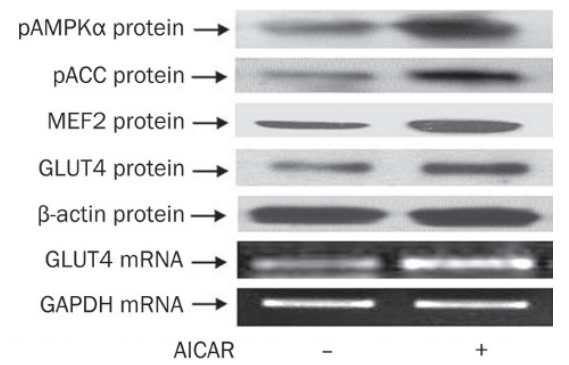

Figure 5. AICAR injection enhanced activation of AMPK, expression of MEF2 and GLUT4 in rat adipose tissue. Six male Wistar rats were subcutaneously injected with $\operatorname{AICAR}(n=3)$ or with a corresponding volume of $0.9 \% \mathrm{NaCl}$ (controls, $n=3$ ). Two hours later, epididymal adipose tissues were obtained for analysis. GLUT4 mRNA expression was measured using RT-PCR. Protein expression of pAMPK $\alpha$, pACC, MEF2, and GLUT4 was determined by Western blotting.

Activated AMPK positively regulates MEF2 and GLUT4 expression in rat and human primary adipocytes

To further confirm the up-regulation of MEF2 and GLUT4 expression by activated AMPK, rat and human primary adipocytes were treated with or without AICAR or compound $\mathrm{C}$ in vitro. As seen in Figure 6, in AICAR-treated rat and human adipocytes, pAMPKa levels increased by $83 \%(P<0.01)$ and $91 \%(P<0.01)$, respectively, and pACC increased by $82 \%(P<0.01)$ and $53 \%(P<0.01)$, respectively. Subsequently, MEF2 levels also increased by $73 \%(P<0.01)$ and $54 \%(P<0.05)$, respectively. Corresponding GLUT4 mRNA levels were elevated by $52 \%(P<0.05)$ and $55 \%(P<0.05)$, respectively, and GLUT4 protein expression increased by $49 \%(P<0.05)$ and $40 \%(P<0.05)$, respectively. These results further confirmed our in vivo observations. However, if cells were preincubated with compound C prior to AICAR for $20 \mathrm{~min}$, the effects of AICAR on activated AMPK, MEF2, and GLUT4 were inhibited to nearly normal levels. These data are consistent with our hypothesis that AMPK is an upstream positive regulator of MEF2 and GLUT4 in rat and human adipocytes.

Inhibition of AMPK activity by ethanol leads to decreased MEF2 and GLUT4 expression in rat and human adipocytes

To investigate the action of ethanol on the AMPK/MEF2/ GLUT4 pathway, isolated rat and human adipocytes were treated with ethanol. Compared to the controls, ethanol decreased pAMPKa protein by 39\% $(P<0.05)$ and 56\% $(P<0.05)$ in rat and human adipocytes, respectively; decreased pACC expression by $49 \%(P<0.05)$ and $56 \%(P<0.01)$, respectively; and decreased MEF2 levels by $32 \%(P<0.05)$ and $45 \%(P<0.05)$, respectively. As a result, the mRNA and protein levels of GLUT4 were diminished by $52 \%(P<0.05)$ and $40 \%(P<0.05)$ in rat adipocytes and by $40 \%(P<0.01)$ and $60 \%(P<0.05)$ in human adipocytes (Figure 7$)$, respectively. Taken together, these results suggest that the impairment of GLUT4 expression by ethanol is most likely due to the decline of AMPK activity and subsequent inhibition of MEF2 expression.

\section{Discussion}

Epidemiological studies suggest that chronic light or heavy ethanol consumption leads to insulin resistance, whereas moderate ethanol consumption results in increased insulin sensitivity ${ }^{[37-41]}$. In the present study, we found that long-term high-dose ethanol consumption led to insulin resistance in rats, which was consistent with previous studies. However, in low-dose ethanol-fed rats, insulin sensitivity as measured by the HOMA index was not statistically different from that of the controls. Consistent with our HOMA insulin sensitivity results, oral glucose tolerance was significantly impaired after high-dose ethanol feeding but did not change after low-dose ethanol consumption. The discrepancy between epidemiological studies and our findings is uncertain but may be due to the following reasons: (1) the HOMA index and OGTT, which were used in our study, are not as sensitive as the hyperinsulinemic euglycemic clamps and intravenous glucose tolerance test (IVGTT) used in the former studies; and (2) the development of insulin resistance and glucose intolerance induced by low-dose ethanol may take longer than 22 weeks and may be related to a threshold total accumulated dose of ethanol.

The mechanisms for the increase in insulin resistance or glucose intolerance induced by ethanol have not been well established. GLUT4 is a key molecule for glucose utilization in adipose tissue and skeletal muscle. The factors that can inhibit GLUT4 expression and/or translocation may lead to a disturbance of glucose utilization. Consistent with previous research ${ }^{[3-5]}$, we found that long-term ethanol consumption decreased GLUT4 expression at both the mRNA and the protein levels in rat adipose tissue. The inhibitory action of ethanol on GLUT4 expression in adipose tissue might be a key step in ethanol-induced insulin resistance, because changes in GLUT4 expression in adipose tissue are considered a key factor in determining whole body insulin sensitivity and may be more important than the changes in both skeletal muscle and 

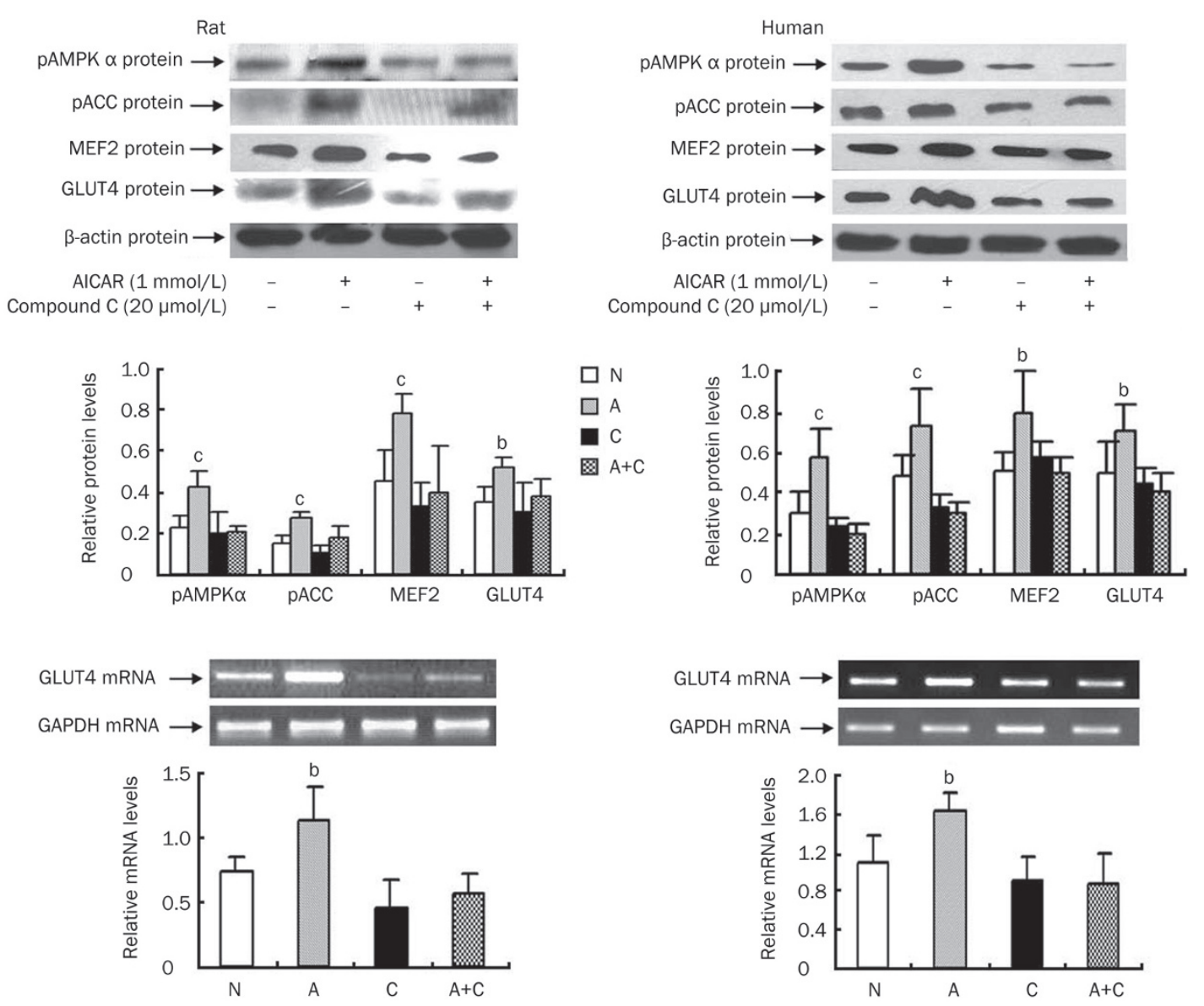

Figure 6. Activated-AMPK was a positive regulator for MEF2 and GLUT4 in rat and human adipocytes. Primary adipocytes were isolated from epididymal fat pad of normal male Wistar rats and omental adipose tissue of male patients who received polyp intestinal surgery. The adipose cells were incubated at $37{ }^{\circ} \mathrm{C}$ for $1 \mathrm{~h}$ in the absence or presence of AICAR $(1 \mathrm{mmol} / \mathrm{L})$ and compound $\mathrm{C}(20 \mu \mathrm{mol} / \mathrm{L})$. Compound $\mathrm{C}$ was supplied for 20 min prior to the addition of AICAR. GLUT4 mRNA expression was measured using RT-PCR. Protein expression of pAMPK $\alpha$, pACC, MEF2, and GLUT4 was determined by Western blotting. The data presented are based on the results of at least four separate experiments. N, control; A, AICAR; C, compound C; $\mathrm{A}+\mathrm{C}$, AICAR plus compound C. ${ }^{\mathrm{b}} P<0.05,{ }^{\mathrm{c}} P<0.01$ vs controls.

liver ${ }^{[1]}$.

Inhibition of GLUT4 mRNA expression prompted us to investigate the mechanism by which ethanol regulates GLUT4 transcription. MEF2 is a transcription factor that plays a key role in skeletal muscle differentiation ${ }^{[42]}$. It contains a known nuclear localization sequence that encompasses amino acids 472-507 in the primary sequence ${ }^{[43]}$, indicating that MEF2 can be translocated to the nucleus. Further studies indicate that MEF2 colocalizes to the nucleus with histone deacetylase $4^{[44]}$. Since the identification of a functional MEF2 binding site located between -522 and -420 in the rat and human GLUT4 promoters ${ }^{[35,36]}$, it is believed that MEF2 is a transcriptional regulator of GLUT4, because the truncation or deletion of this binding sequence in the GLUT4 promoter decreases GLUT4 mRNA expression ${ }^{[36]}$.

In the present study, we found that chronic ethanol consumption decreased MEF2A and MEF2D expression at both the mRNA and the protein levels in rat adipose tissue. The inhibition of MEF2 expression by ethanol may help us to understand the decrease in GLUT4 mRNA expression. The reduced nuclear MEF2A and MEF2D levels could have resulted in the decreased formation of the MEF2A/MEF2D heterodimer. Subsequently, the heterodimers that bind to the GLUT4 promoter would also be decreased, which in turn would result in impaired GLUT4 expression. Based on our present results, we could not determine which isoform of MEF2 was most important for GLUT4 gene expression. However, based on other reports, it seems that MEF2D is more important than MEF2A in regulating GLUT4 expression in adipose tissue. Knight et al demonstrated that MEF2A, but not MEF2D, is an activator of the GLUT4 promoter ${ }^{[45]}$ in the pancreas, kidney, skeletal muscle, liver, lung, placenta, brain, and heart. However, Mora et al ${ }^{[46]}$ found that, in contrast to both cardiac and skeletal muscle, adipose tissue displays a selective decrease in MEF2D expression in diabetes without any significant alteration in MEF2A protein content. Furthermore, in vivo, the selective overexpression of MEF2A in adipose tissue does not affect GLUT4 expression and is not sufficient to pre- 

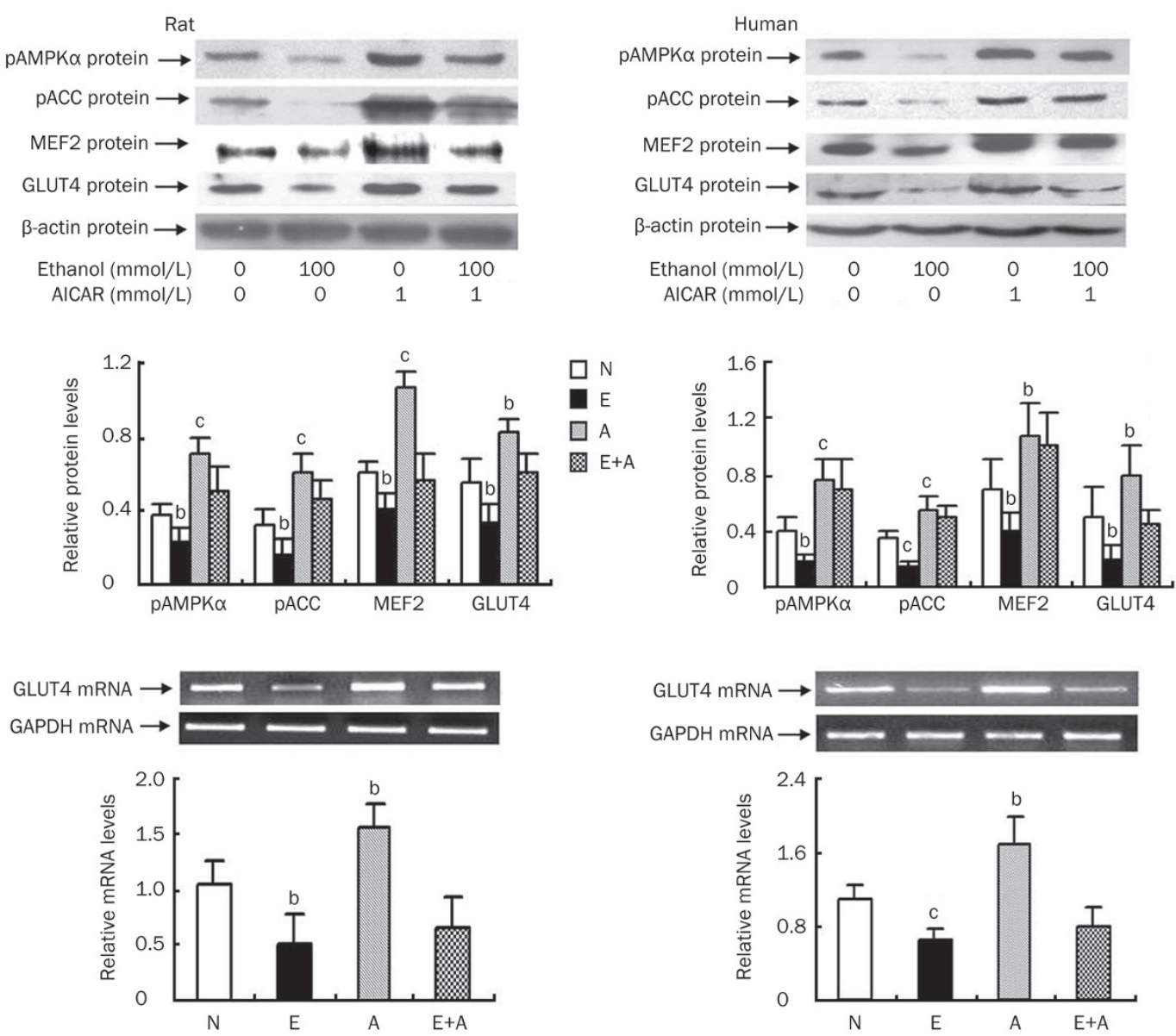

Figure 7. Ethanol-treatment impaired AMPK/MEF2/GLUT4 pathway in rat and human adipocytes. Rat and human primary adipocytes were isolated as previously described (Materials and Methods). The cells were incubated at $37^{\circ} \mathrm{C}$ for $1 \mathrm{~h}$ in the absence or presence of ethanol (100 mmol/L) and AICAR (1 mmol/L). GLUT4 mRNA expression was measured using RT-PCR. Protein expression of pAMPK $\alpha$, pACC, MEF2, and GLUT4 was determined by Western blotting. The data presented are based on the results of at least four separate experiments. N, control; E, ethanol; A, AICAR; E+A, ethanol plus AICAR. ${ }^{\mathrm{b}} P<0.05,{ }^{\mathrm{c}} P<0.01$ vs controls.

vent the GLUT4 downregulation that occurs in insulin-deficient states $^{[46]}$. The reason for the discrepancy between their results is still unclear, but the different tissues utilized might be a possible explanation. The relationships between the two isoforms of MEF2 and GLUT4 need further exploration.

AMPK has been demonstrated to be an upstream regulator for MEF2 and can increase MEF2 expression in skeletal muscle, resulting in up-regulation of GLUT4 transcription ${ }^{[47,48]}$. The existence of this mechanism in adipose tissue after ethanoltreatment has not been studied. We investigated the expression of AMPKa1 and a2 mRNA, total AMPKa, and pAMPKa protein in ethanol-treated rat adipose tissue. Our results show that feeding rats ethanol resulted in a reduction in pAMPKa level without any significant effect on AMPKa1/2 mRNA or total AMPKa protein level, suggesting that ethanol affects the activation, but not expression of AMPKa. Activated AMPK can be translocated to the nucleus from the cytosol ${ }^{[48]}$, which could be the reason that MEF2 is affected at a transcriptional level in the nucleus. As an indicator of pAMPK activation, the decline in pACC further confirmed the decreased activation of
AMPK after long-term ethanol feeding.

Although low-dose ethanol showed no significant influence on insulin sensitivity or glucose tolerance, the expression of AMPK, MEF2, and GLUT4 in rat adipose tissue was significantly reduced. Based on these findings, it is possible to conclude that changes at the molecular level may take place before any pathological consequences and that, with time, the negative effect of ethanol on insulin sensitivity will gradually become more significant.

In skeletal muscle, activated AMPK has been demonstrated to increase GLUT4 protein level and translocation ${ }^{[21,49,50]}$ via $\mathrm{MEF}^{[25,27,48]}$. However, the findings in adipose tissue are controversial. Under basal conditions (no insulin stimulation), several studies have reported that the activation of AMPK by AICAR accelerates GLUT4 translocation and increases glucose uptake ${ }^{[23,24]}$, whereas others have shown that glucose uptake is suppressed by activated AMPK in adipocytes, probably due to decreased translocation of GLUT4 ${ }^{[51]}$.

To test whether an AMPK/MEF2/GLUT4 pathway existed in adipose tissues and to observe the regulation of MEF2 
and subsequent GLUT4 expression by AMPK in vivo and in vitro, rats were subcutaneously injected with AICAR, and adipocytes isolated from rat and human adipose tissues were treated with or without AICAR or compound C. Our results show that AICAR increased pAMPKa levels in both adipose tissue and adipocytes. Parallel to the changes in pAMPKa, the level of pACC was also enhanced. Because ACC is a cytosolic protein and an indicator of AMPK activation, the increased pACC level reflects enhanced AMPK activation in the cytosol. As a downstream molecule of AMPK in the nucleus, MEF2 expression was elevated after AICAR treatment. Therefore, from these results, we conclude that enhanced activation of AMPK increased MEF2 expression.

MEF2 is reported to be a transcriptional regulator of GLUT4 in skeletal muscle. Therefore, we wanted to know whether increased MEF2 expression would lead to a rise in GLUT4 mRNA expression in adipocytes. As expected, both GLUT4 mRNA and protein levels were enhanced in AICAR-treated rat and human adipocytes. In adipocytes treated with the AMPK inhibitor compound C prior to AICAR for $20 \mathrm{~min}$, the augmentation effects of AICAR on activated AMPK, MEF2, and GLUT4 levels were inhibited to a level close to normal. These findings indicate that GLUT4 expression in adipocytes is positively regulated by activated AMPKa via MEF2.

To further confirm the action of ethanol on the AMPK/ MEF2/GLUT4 pathway observed in vivo, primary adipocytes isolated from rat and human adipose tissue were incubated with ethanol. AMPK activation and MEF2 expression were inhibited by ethanol. Accordingly, mRNA and protein expression of GLUT4 were suppressed. The changes in this pathway in vitro further confirmed the findings we observed in vivo. However, the in vitro incubation time was only $1 \mathrm{~h}$, which was not long enough to mimic the chronic effects of ethanol. We incubated cells for only $1 \mathrm{~h}$ for the following reasons. In our preliminary experiments, the longest survival time of isolated mature adipocytes was no more than $24 \mathrm{~h}$. Moreover, in the preliminary experiments, we incubated the rat adipocytes with $100 \mathrm{mmol} / \mathrm{L}$ ethanol for different times (data not shown). The maximum inhibitory effect on AMPK phosphorylation was observed when adipocytes were treated with $100 \mathrm{mmol} / \mathrm{L}$ ethanol for $1 \mathrm{~h}$. The inhibitory effect of ethanol was not enhanced when the incubation was prolonged to $120 \mathrm{~min}$. Furthermore, ethanol is a volatile substance. With decreases of ethanol concentration in the medium, the inhibitory effect of ethanol was weakened. Therefore, to maintain cell activity and mimic the effects of high-dose ethanol in vitro, one hour was chosen for the in vitro experiments.

In an earlier study, we reported that the addition of ethanol to a high fat diet ameliorated the effects of the high fat diet and increased GLUT4 expression. In the present study, we found that ethanol decreased GLUT4 expression. The findings clearly indicate that the effect of ethanol on GLUT4 expression is more complex than previously thought. A comparison of the two experiments suggests some possible reasons for the discrepancy. First, although the animals in both studies received the same total daily ethanol dosage, the frequencies of ethanol intake were different. Previously, rats received ethanol twice daily, while here they received it only once daily. The different frequencies of ethanol intake led to different plasma ethanol concentrations $(87 \pm 24.9 \mathrm{mg} / \mathrm{dL}$ in the present study, $10.8 \pm 3.6 \mathrm{mg} / \mathrm{dL}$ in the earlier experiment), resulting in different outcomes even though the average daily ethanol consumption was similar ${ }^{[52,53]}$. Administration of ethanol once daily at 0.5 and $5 \mathrm{~g} / \mathrm{kg}$ might mimic the effects of light and heavy ethanol consumption, respectively, whereas twice daily administration at the dosage of $5 \mathrm{~g} / \mathrm{kg}$ might mimic the effects of moderate ethanol consumption. Second, it is possible that a counteractive effect may exist between ethanol and a high-fat diet. For example, ethanol attenuates fatty acid-induced apoptosis in neonatal rat cardiomyocytes ${ }^{[54]}$. Diets rich in saturated fatty acids protect against alcoholic liver injury ${ }^{[55-60]}$. Furthermore, administration of saturated fat has been shown to reverse established alcoholic liver injury in rats and improve nearly all liver pathological changes, despite continued ethanol administration ${ }^{[61,62]}$. Based on these data, our present findings suggest that the adverse effects of a high-fat diet might be countered by the addition of ethanol, with a restoration of GLUT4 expression, but that such an effect would not be observed when rats were fed a normal diet.

In conclusion, we demonstrate that an AMPK/MEF2/ GLUT4 pathway exists in adipose tissue and that activated AMPK up-regulates GLUT4 expression via MEF2. Inhibition of this pathway by long-term ethanol feeding, at least in part, contributes to the impairment of GLUT4 expression in adipose tissue, thus decreasing insulin sensitivity and glucose tolerance.

\section{Acknowledgments}

This work was supported by grants from the National Natural Science Foundation of China (No 30940038) and the Natural Science Foundation of Shandong Province, China (№ 2009ZRB14271, Y2001C12). The authors acknowledge the expert technical assistance by teachers in the central laboratory and experimental animal center of the Provincial Hospital affiliated to Shandong University. The authors thank Prof Harvest F GU for critical review of the manuscript. Partial data from this work were presented at the 67th ADA Annual Meeting (2007-A-2399-Diabetes), 43rd EASD Annual Meeting (A-07-2149-EASD), 44th EASD Annual Meeting (A-08-1890EASD), and 45th EASD Annual Meeting (A-09-2096-EASD).

\section{Author contribution}

Li FENG and Yong-feng SONG did most of the work in this research, such as feeding animals, isolating adipocytes, performing experiments, and writing article. Qing-bo GUAN provided help for the experiment designing. Hong-jun LIU helped the first author collect human adipose tissues for adipocytes isolation. Bo BAN and Hai-xin DONG helped the first author determine plasma ethanol concentration. Xiao-lei HOU helped the first author prepare the animals. Kok-Onn LEE critically edited the manuscript. Jia-jun ZHAO and Ling GAO are corresponding authors, they designed the experiment and 
supply essential support of technology and fund.

\section{Abbreviations}

MPK, AMP-activated protein kinase; MEF2, myocyte enhancer factor 2; GLUT4, glucose transporter 4; GAPDH, glyceraldehyde3-phosphate dehydrogenase

\section{References}

1 Minokoshi Y, Kahn CR, Kahn BB. Tissue-specific ablation of the GLUT4 glucose transporter or the insulin receptor challenges assumptions about insulin action and glucose homeostasis. J Biol Chem 2003; 278: 33609-12.

2 Shepherd PR, Gnudi L, Tozzo E, Yang H, Leach F, Kahn BB. Adipose cell hyperplasia and enhanced glucose disposal in transgenic mice overexpressing GLUT4 selectively in adipose tissue. J Biol Chem 1993; 268: 22243-6.

3 Chen L, Nyomba BL. Effects of prenatal alcohol exposure on glucose tolerance in the rat offspring. Metabolism 2003; 52: 454-62.

4 Wilkes JJ, Nagy LE. Chronic ethanol feeding impairs glucose tolerance but does not produce skeletal muscle insulin resistance in rat epitrochlearis muscle. Alcohol Clin Exp Res 1996; 20: 1016-22

5 Poirier LA, Rachdaoui N, Nagy LE. GLUT4 vesicle trafficking in rat adipocytes after ethanol feeding: regulation by heterotrimeric G-proteins. Biochem J 2001; 354: 323-30.

6 Feng L, Gao L, Guan Q, Hou X, Wan Q, Wang X, et al. Long-term moderate ethanol consumption restores insulin sensitivity in highfat-fed rats by increasing GLUT4 in the adipose tissue by AMPK activation. J Endocrinol 2008; 199: 95-104.

7 Qu W, Hao L, Chen Y, Zhou S. Effect of chronic ethanol intake on insulin receptor, insulin receptor subsrate-1 and phosphoinositide 3-kinase mRNA expression in skeletal muscle of rats. Wei Sheng Yan Jiu 2007; 36: 172-5.

8 Zhou SL, Hao LP, Chen YY, Qu W. Influence of chronic ethanol intake on insulin sensitivity and IR, IRS-1, IRS-2 mRNA expression of liver in male rats. Wei Sheng Yan Jiu 2006; 35: 294-6.

9 Wan Q, Liu Y, Guan Q, Gao L, Lee KO, Zhao J. Ethanol feeding impairs insulin-stimulated glucose uptake in isolated rat skeletal muscle: role of Gs alpha and cAMP. Alcohol Clin Exp Res 2005; 29: 1450-6.

10 Sebastian BM, Nagy LE. Decreased insulin-dependent glucose transport by chronic ethanol feeding is associated with dysregulation of the Cbl/TC10 pathway in rat adipocytes. Am J Physiol Endocrinol Metab 2005; 289: E1077-1084.

11 García-Villafranca J, Guillén A, Castro J. Ethanol consumption impairs regulation of fatty acid metabolism by decreasing the activity of AMPactivated protein kinase in rat liver. Biochimie 2008; 90: 460-6.

12 You M, Matsumoto M, Pacold CM, Cho WK, Crabb DW. The role of AMP-activated protein kinase in the action of ethanol in the liver. Gastroenterology 2004; 127: 1798-808.

13 Chakraborty G, Saito M, Mao RF, Wang R, Vadasz C, Saito M. Lithium blocks ethanol-induced modulation of protein kinases in the developing brain. Biochem Biophys Res Commun 2008; 367: $597-$ 602.

14 Saito M, Chakraborty G, Mao RF, Wang R, Cooper TB, Vadasz C, et al. Ethanol alters lipid profiles and phosphorylation status of AMPactivated protein kinase in the neonatal mouse brain. J Neurochem 2007; 103: 1208-18.

15 Hong-Brown LQ, Brown CR, Huber DS, Lang $\mathrm{CH}$. Alcohol regulates eukaryotic elongation factor 2 phosphorylation via an AMP-activated protein kinase-dependent mechanism in $\mathrm{C} 2 \mathrm{C} 12$ skeletal myocytes. J Biol Chem 2007; 282: 3702-12.
16 Carling D. The AMP-activated protein kinase cascade - a unifying system for energy control. Trends Biochem 2004; 29: 18-24.

17 Kemp BE, Mitchelhill KI, Stapleton D, Michell BJ, Chen ZP, Witters LA. Dealing with energy demand: the AMP-activated protein kinase. Trends Biochem Sci 1999; 24: 22-5.

18 Stapleton D, Mitchelhill KI, Gao G, Widmer J, Michell BJ, Teh T, et al. Mammalian AMP-activated protein kinase subfamily. J Biol Chem 1996; 271: 611-4.

19 Hardie DG, Carling D, Carlson M. The AMP-activated/SNF1 protein kinase subfamily: metabolic sensors of the eukaryotic cell. Annu Rev Biochem 1998; 67: 821-55.

20 Jessen N, Pold R, Buhl ES, Jensen LS, Schmitz O, Lund S. Effects of AICAR and exercise on insulin-stimulated glucose uptake, signaling, and GLUT-4 content in rat muscles. J Appl Physiol 2003, 94: 1373-9.

21 Kurth-Kraczek EJ, Hirshman MF, Goodyear $\sqcup$, Winder WW. 5' AMPactivated protein kinase activation causes GLUT4 translocation in skeletal muscle. Diabetes 1999; 48: 1667-71.

22 Sakoda H, Ogihara T, Anai M, Fujishiro M, Ono H, Onishi Y, et al. Activation of AMPK is essential for AICAR-induced glucose uptake by skeletal muscle but not adipocytes. Am J Physiol Endocrinol Metab 2002; 282: E1239-E1244.

23 Salt IP, Connell JM, Gould GW. 5-aminoimidazole-4-carboxamide ribonucleoside (AICAR) inhibits insulin-stimulated glucose transport in 3T3-L1 adipocytes. Diabetes 2000; 49: 1649-56.

24 Yamaguchi S, Katahira H, Ozawa S, Nakamichi Y, Tanaka T, Shimoyama T, et al. Activators of AMP-activated protein kinase enhance GLUT4 translocation and its glucose transport activity in 3T3-L1 adipocytes. Am J Physiol Endocrinol Metab 2005; 289: E643-E649.

25 Al-Khalili L, Chibalin AV, Yu M, Sjodin B, Nylen C, Zierath JR, et al. MEF2 activation in differentiated primary human skeletal muscle cultures requires coordinated involvement of parallel pathways. Am J Physiol Cell Physiol 2004; 286: C1410-C1416.

26 Mora S, Pessin JE. The MEF2A isoform is required for striated muscle-specific expression of the insulin-responsive GLUT4 glucose transporter. J Biol Chem 2000; 275: 16323-8.

27 Zheng D, MacLean PS, Pohnert SC, Knight JB, Olson AL, Winder WW, et al. Regulation of muscle GLUT-4 transcription by AMP-activated protein kinase. J Appl Physiol 2001; 91: 1073-83.

28 Matthews DR, Hosker JP, Rudenski AS, Naylor BA, Treacher DF, Turner RC. Homeostasis model assessment: insulin resistance and beta-cell function from fasting plasma glucose and insulin concentrations in man. Diabetologia 1985; 28: 412-9.

29 Tanti JF, Cormont M, Gremeaux T, Le Marchand-Brustel Y. Assays of glucose entry, glucose transporter amount, and translocation. In: Ailhaud G, Ed. Methods in molecular biology. Vol 155: Adipose Tissue Protocols. Totowa (NJ): Humana Press; 2001. p 157-65,

30 Wu X, Motoshima H, Mahadev K, Stalker TJ, Scalia R, Goldstein BJ. Involvement of AMP-activated protein kinase in glucose uptake stimulated by the globular domain of adiponectin in primary rat adipocytes. Diabetes 2003; 52: 1355-63.

$31 \mathrm{Li} \mathrm{H}$, Kim KH. Effects of ethanol on embryonic and neonatal rat testes in organ cultures. J Androl 2003; 24: 653-60.

32 Szabo G, Puppolo M, Verma B, Catalano D. Regulatory potential of ethanol and retinoic acid on human monocyte functions. Alcohol Clin Exp Res 1994; 18: 548-54.

33 He L, Marecki JC, Serrero G, Simmen FA, Ronis MJ, Badger TM. Dosedependent effects of alcohol on insulin signaling: partial explanation for biphasic alcohol impact on human health. Mol Endocrinol 2007, 21: 2541-50.

34 Bierhaus A, Schiekofer S, Schwaninger M, Andrassy M, Humpert 
PM, Chen J, et al. Diabetes-associated sustained activation of the transcription factor nuclear factor-kappaB. Diabetes 2001; 50 : 2792-808.

35 Ezaki O. Regulatory elements in the insulin-responsive glucose transporter (GLUT4) gene. Biochem Biophys Res Commun 1997; 241 : 1-6.

36 Liu ML, Olson AL, Edgington NP, Moye-Rowley WS, Pessin JE. Myocyte enhancer factor 2 (MEF2) binding site is essential for $\mathrm{C} 2 \mathrm{C} 12$ myotubespecific expression of the rat GLUT4/muscle-adipose facilitative glucose transporter gene. J Biol Chem 1994; 269: 28514-21.

37 Bell RA, Mayer-Davis EJ, Martin MA, D'Agostino RB Jr, Haffner SM. Associations between alcohol consumption and insulin sensitivity and cardiovascular disease risk factors: the Insulin Resistance and Atherosclerosis Study. Diabetes Care 2000; 23: 1630-6.

38 Cooper DE, Goff DC Jr, Bell RA, Zaccaro D, Mayer-Davis EJ, Karter AJ. Is insulin sensitivity a causal intermediate in the relationship between alcohol consumption and carotid atherosclerosis: the insulin resistance and atherosclerosis study. Diabetes Care 2002; 25: 1425-31.

39 Dixon JB, Dixon ME, O'Brien PE. Alcohol consumption in the severely obese: relationship with the metabolic syndrome. Obes Res 2002; 10: 245-52.

40 Goude D, Fagerberg B, Hulthe J, AIR Study Group. Alcohol consumption, the metabolic syndrome and insulin resistance in 58-year-old clinically healthy men (AIR study). Clin Sci 2002; 102: 345-52.

41 Zilkens RR, Burke V, Watts G, Beilin LJ, Puddey IB. The effect of alcohol intake on insulin sensitivity in men: a randomized controlled trial. Diabetes Care 2003; 26: 608-12.

42 Black BL, Olson EN. Transcriptional control of muscle development by myocyte enhancer factor-2 (MEF2) proteins. Annu Rev Cell Dev Biol 1998; 14: 167-96.

$43 \mathrm{Yu} \mathrm{YT}$. Distinct domains of myocyte enhancer binding factor-2A determining nuclear localization and cell type-specific transcriptional activity. J Biol Chem 1996; 271: 24675-83.

44 Borghi S, Molinari S, Razzini G, Parise F, Battini R, Ferrari S. The nuclear localization domain of the MEF2 family of transcription factors shows member-specific features and mediates the nuclear import of histone deacetylase 4. J Cell Sci 2001; 114: 4477-83.

45 Knight JB, Eyster CA, Griesel BA, Olson AL. Regulation of the human GLUT4 gene promoter: interaction between a transcriptional activator and myocyte enhancer factor 2A. Proc Natl Acad Sci USA 2003; 100: 14725-30.

46 Mora S, Yang C, Ryder JW, Boeglin D, Pessin JE. The MEF2A and MEF2D isoforms are differentially regulated in muscle and adipose tissue during states of insulin deficiency. Endocrinology 2001; 142: 1999-2004.

47 Giri S, Rattan R, Haq E, Khan M, Yasmin R, Won JS, et al. AICAR inhibits adipocyte differentiation in 3T3L1 and restores metabolic alterations in diet-induced obesity mice model. Nutr Metab 2006; 3: 31.

48 Holmes BF, Sparling DP, Olson AL, Winder WW, Dohm GL. Regulation of muscle GLUT4 enhancer factor and myocyte enhancer factor 2 by
AMP-activated protein kinase. Am J Physiol Endocrinol Metab 2005; 289: E1071-E1076.

49 Buhl ES, Jessen N, Schmitz O, Pedersen SB, Pedersen O, Holman $\mathrm{GD}$, et al. Chronic treatment with 5-aminoimidazole-4-carboxamide1-beta-D-ribofuranoside increases insulin-stimulated glucose uptake and GLUT4 translocation in rat skeletal muscles in a fiber type-specific manner. Diabetes 2001; 50: 12-7.

50 Koistinen HA, Galuska D, Chibalin AV, Yang J, Zierath JR, Holman GD, et al. 5-amino-imidazole carboxamide riboside increases glucose transport and cell-surface GLUT4 content in skeletal muscle from subjects with type 2 diabetes. Diabetes 2003, 52: 1066-72.

51 Gaidhu MP, Fediuc S, Ceddia RB. 5-Aminoimidazole-4-carboxamide1-beta-D-ribofuranoside - induced AMP-activated protein kinase phosphorylation inhibits basal and insulin-stimulated glucose uptake, lipid synthesis, and fatty acid oxidation in isolated rat adipocytes. J Biol Chem 2006; 281: 25956-64.

52 Zakhari S, Li TK. Determinants of alcohol use and abuse: Impact of quantity and frequency patterns on liver disease. Hepatology 2007; 46: 2032-9.

53 Fan AZ, Russell M, Naimi T, Li Y, Liao Y, Jiles R, et al. Patterns of alcohol consumption and the metabolic syndrome. J Clin Endocrinol Metab 2008; 93: 3833-8.

54 Sparagna GC, Jones CE, Hickson-Bick DL. Attenuation of fatty acidinduced apoptosis by low-dose alcohol in neonatal rat cardiomyocytes. Am J Physiol Heart Circ Physiol 2004; 287: H2209-H2215.

55 Nanji AA, Mendenhall CL, French SW. Beef fat prevents alcoholic liver disease in the rat. Alcohol Clin Exp Res 1989; 13: 15-9.

56 Nanji AA, Sadrzadeh SM, Yang EK, Fogt F, Meydani M, Dannenberg AJ. Dietary saturated fatty acids: a novel treatment for alcoholic liver disease. Gastroenterology 1995; 109: 547-54.

57 Mezey E. Dietary fat and alcoholic liver disease. Hepatology 1998; 28: 901-5.

58 Satoh S, Uetake S, Ohata M, Nakajima H, Yamauchi M. Effect of type of dietary fat and ethanol on hepatic leukotriene level in experimental alcoholic liver disease. Nihon Nihon Arukoru Yakubutsu Igakkai Zasshi 2003; 38: 350-63.

59 Ronis MJ, Korourian S, Zipperman M, Hakkak R, Badger TM. Dietary saturated fat reduces alcoholic hepatotoxicity in rats by altering fatty acid metabolism and membrane composition. J Nutr 2004; 134: 904-12.

60 You M, Considine RV, Leone TC, Kelly DP, Crabb DW. Role of adiponectin in the protective action of dietary saturated fat against alcoholic fatty liver in mice. Hepatology 2005; 42: 568-77.

61 Nanji AA, Yang EK, Fogt F, Sadrzadeh SM, Dannenberg AJ. Medium chain triglycerides and vitamin $E$ reduce the severity of established experimental alcoholic liver disease. J Pharmacol Exp Ther 1996; 277: 1694-700.

62 Nanji AA, Jokelainen K, Tipoe GL, Rahemtulla A, Dannenberg AJ. Dietary saturated fatty acids reverse inflammatory and fibrotic changes in rat liver despite continued ethanol administration. J Pharmacol Exp Ther 2001; 299: 638-44. 